УДК 94:[378.096:355(477.83-25)]:329.15(47+57) «1944/1991»

ШЕЛЕСТАК Л. Р.

https://orcid.org/0000-0001-8673-3931

https://doi.org/10.33577/2313-5603.31.2019.99-111

\title{
ВІЙСЬКОВА КАФЕДРА ЛЬВІВСЬКОГО ПОЛІТЕХНІЧНОГО ІНСТИТУТУ НА СЛУЖБІ РАДЯНСЬКОЇ ІДЕОЛОГІЇ (1944-1991)
}

Розглянуто та проаналізовано політико-пропагандистську діяльність військової кафедри Львівського політехнічного інституту. У студії використано архівні матеріали, статті періодики, нормативно-правові акти радянських органів влади, інформація інтерв'ю із випускниками військової кафедри Інституту. На основі використаних матеріалів проаналізовано військово-політичне навчання студентів, методи і форми пропаганди комуністичної ідеології офіцерами кафедри радянської ідеології для молоді Галичини. Авторка дійшла низки висновків: військова кафедра Львівського політехнічного інституту проводила активну політико-пропагандистську роботу зі студентами, яких часто залучали до різного роду політичних заходів та святкувань, була важливою ідеологічною одиницею вишу. Водночас на офіцерів військової кафедри була покладена місія вишколити достатньо фахових офіцерів запасу Радянської Армії.

Ключові слова: військова кафедра, Львівський політехнічний інституг, ідеологія, офіцери запасу.

Радянську систему військового вишколу розпочали розгортати у вишах Львова в останній період німецько-радянської війни, Наказом наркома оборони СРСР № 75 та Постановою РНК СРСР № 413 від 13 квітня 1944 року, за якими у вищих цивільних навчальних закладах СРСР мали відновити військове і військовоморське навчання студентів. Згідно із цими правовими документами військовий вишкіл студентів мав на меті «виховати студентську молодь в любові до Батьківщини і відданості радянській владі...» (Совет Народных Комиссаров СССР. Постановление № 413 «O военной подготовке студентов высших учебных заведений», 1944). Військову кафедру Львівського політехнічного інституту (далі ЛПІ) засновано після відновлення діяльності Інституту на початку 1944 - 1945 н. p. згідно з Наказом Всесоюзного комітету у справах

Шелестак Лариса Романівна, магістр історії, аспірант кафедри історичного краєзнавства Львівського національного університету імені Івана Франка, м. Львів.

() Шелестак Л.Р., 2019 
вищої школи при РНК СРСР № 86 від 16 вересня 1944 р. «Про затвердження структури інституту» (Історична довідка ЛПІ, арк. 6).

Джерельна база дослідження є достатньою та різноманітною. Передусім автор використала матеріали Державного архіву Львівської області: фонд Львівського політехнічного інституту радянського періоду Р-120 - це, насамперед, протоколи засідання військової кафедри. Із фонду Партійного комітету ЛПІ - П-380 використано протоколи партійних зібрань кафедри та протоколи партійного бюро кафедри. Для аналізу пропагандистської діяльності офіцерів військової кафедри використано матеріали інститутської газети, органу партійного комітету, студентського профкому та профкому працівників інституту - «Радянський студент», зокрема статті самих офіцерів кафедри та начерки студентів про власний військовий досвід. Для підтвердження авторських міркувань використано інтерв'ю із випускниками ЛПІ, тези яких дають нам певну оцінкову характеристику політичної роботи кафедри. Щодо історіографії досліджуваної проблеми, важливою для нас є інформація статті «Студентство України за демократичне вирішення питання військової підготовки наприкінці 80-х - початку 90-х років XX ст.» львівського науковця Олега Муравського, основною проблематикою якої є студентські протести кінця 1980 -х років.

Авторка поставила за мету дослідити роль військової кафедри в політичному вихованні студентів одного із найбільших вишів Львова радянського періоду, всебічно розглянути ідейно-політичну діяльність офіцерів кафедри. Завдання студії: дослідити основні шляхи інформування та поширення комуністичних догм, популяризації військової служби та досягнень радянської військової справи офіцерами військової кафедри, методи політичного впливу на студентську молодь.

Від початку свого створення військова кафедра Львівського політехнічного інституту як структурна одиниця вже радянського вишу виконувала ідейно-виховну функцію. За кожним факультетом призначали офіцера, який не лише відповідав за військове навчання студентів, створення військово-наукових гуртків та секцій, але й складав на кожного студента, що навчався на військовій кафедрі, так звану особову справу: вивчав повну біографію, особисті дані студента, характеристики 3 деканату (Протоколи засідань партійного бюро за 1950 р., 1950, арк. 68) та комсомольської організації (Протоколь заседаний кафедры за 1952-1953 учебный год, 1953, арк. 24 зв.). 
Зважаючи на те, що на Галичині в кінці 1940-х - на початку 1950-х років діяло підпілля ОУН, у вищих навчальних закладах проводились репресії щодо студентів, які могли бути пов'язані із націоналістами. 3 цього приводу в 1950 р. на засіданні партійного комітету Львівського політехнічного інституту обговорювали роботу відділу кадрів та приймальної комісії щодо їхньої пильності у прийомі документів і вказаних у них біографічних даних абітурієнтів. Зокрема, негативно висловлювались про механізм прийому студентів до Інституту і представники військової кафедри. Так начальник військової кафедри упродовж 1946 - 1957 рр., генералмайор А.П. Голубєв наголошував, що завданням кафедри військової підготовки була атестація студентів, а в особових справах не зазначено інформацію про рідних та чи були вони на окупованій території. Інженер-полковник Л.Г. Кніна запропонував вимагати у студентів через деканати повні біографії, щоб порівняти їх з тими, що вже були в особових справах, та краще вивчити студентство (Протоколи засідань партійного бюро за 1950 р., 1950, арк. 68).

У 1952 р. трапився випадок відрахування студентів із Інституту за «націоналістичну пропаганду», який активно обговорювали на засіданні військової кафедри. Відрахованими були студенти п'ятого курсу Шах і Шалівський. Незважаючи на добру характеристику та атестацію офіцерів запасу Радянської Армії, вони так і не були в комсомолі (Протоколь заседаний кафедры за 19511952 учебный год, 1952, арк. 33 зв.). Студенти друкували агітаційні листівки на горищі гуртожитку, а відтак були заарештовані як «вороги народу» (Протоколь заседаний кафедры за 1951-1952 учебный год, 1952, арк. 34.). Начальник кафедри наголошував, що велика кількість студентів має добрі характеристики та успішність, але у своїй біографії зазначали, що батько чи матір репресовані або мали родичів, зв'язаних із «бандерівцями». Тому закликав краще вивчати самих студентів, збирати автобіографічні дані студентів другого і четвертого курсів, тобто тих, хто проходив табірні збори (Протоколь заседаний кафедры за 1951-1952 учебный год, 1952, арк. 33 зв.).

Як члени ВКП(б) (згодом КПРС), офіцери кафедри вважали за потрібне вдосконалити механізм вивчення біографії студентів, які тільки-но потрапляли на військову кафедру. Полковник Григорян зауважував, що він, як курсовий офіцер, за наказом писав характеристики на студентів, яких він не знав, користуючись лише 
інформацією із характеристики декана факультету (Протоколь заседаний кафедры за 1951-1952 учебный год, 1952, арк. 34). Майор Шабанов на засіданні кафедри висловився: «ворог пішов у підпілля $і$ застосовує всі засоби щуоб втайти свою роботу. Не потрібно забувати те, щзо ми живемо там, де є сильний націоналістичний рух і тому нам слід бути пильними» (Протокольь заседаний кафедры за 1951-1952 учебный год, 1952, арк. 35). Попри самокритичне ставлення офіцерів до якості політичної роботи кафедри, спостереження за студентами в інституті велись на потрібному, для радянських репресивних органів рівні. Наприклад, у 1951 р. на табірних зборах офіцери дізналися, що студент хіміко-технічного факультету Бєлогаєв був заарештований та перебував у полоні.

Також під підозру потрапляли студенти, які з різних причин часто пропускали заняття в Інституті (Протоколь заседаний кафедры за 1951-1952 учебный год, 1952, арк. 34 зв.). Цікаво й те, що траплялися випадки, коли самі студенти скаржилися в деканат чи громадські організації при факультеті, що їм заважало вступати в комсомол. Наприклад, студент четвертого курсу Попович скаржився, що не може вступити в комсомол, бо боявся, що його вб'ють «бандерівці» (Протоколь заседаний кафедры за 1951-1952 учебный год, 1952, арк. 34).

Офіцери військової кафедри часто писали статті у студентське періодичне видання інституту «Радянський студент», які стосувалися радянських державних свят, відзначення річниць військовополітичних подій в СРСР, а також статті про військових теоретиків та історію зброї. Звичайно, всі вони мали ідеологічний характер, звеличували роль військової сили Радянського Союзу, часточкою якої були і вони. «Партія Леніна-Сталіна - натхненник і організатор перемог»- газетна стаття до дня Радянської Армії, авторства генерал-майора А.П. Голубєва, у якій він розглядав воєнні події німецько-радянської війни крізь призму радянської політичної ідеології (Голубєв, 1947:2).

Викладачі військової кафедри були активними дописувачами газетних публікацій ідеологічного вмісту, їхнім завданням було донести до студентської молоді інформацію про успіхи Радянської Армії, ії досягнення у військовій справі. Так майор І. Ляшенко присвятив статтю «Артилерія Радянської Армії» до дня артилерійських військ СРСР (19 листопада) (Ляменко, 1947:2). 
Стаття підполковника Г. Мадєєва «Конструктор російської гвинтівки» була присвячена 100-річчю з дня народження С. І. Мосіна, першого в Росії розробника конструкції магазинної гвинтівки трилінійної гвинтівки зразка 1891 р. (Мадеєв, 1949:4), яку активно використовувала Радянська Армія до середини 1970-х років.

Важливі теми, які піднімали викладачі військової кафедри, стосувалися їхньої бойової участі у Другій світовій війні. Часто викладачі залучали студентів, щоб ті поділилися своїми спогадами iз однолітками на різного роду лекціях та на сторінках студентської газети. Це були короткі, інколи автобіографічні, замітки самих студентів про їхнє перебування на війні. Писали їх студенти різних факультетів, різних курсів. В основному, це була інформація про випадок із життя на фронті, про бій та захоплення у полон німецьких військовиків, форсування річок (Чернілевський, 1947:3), облоги українських міст (Кулик, 1947:3).

Упродовж 1960-х - 1970-х років офіцери військової кафедри організовували зустрічі студентів із ветеранами Другої світової війни (Сморчков, 1975:2), проводили молодіжні вечори на факультетах, присвячені військово-історичним подіям (Протокольы партийных собраний военной кафедры ЛПИ (17.03.1960-29.12.1960), 1960, арк. 78), а також екскурсії в музей Прикарпатського військового округу, Львівську філію Центрального музею В. Леніна та місцями боїв німецько-радянської війни (Зінченко, 1947:2).

Часто із виховною метою на військовій кафедрі проводили ленінські читання, колективні перегляди кінофільмів, політінформації. Студентів залучали до проведення заходів у Будинку офіцерів (Рожков, 1988:3) та парадів на честь радянських свят.

Однак, як свідчать студенти, що навчалися на військовій кафедрі ЛПІ, зокрема на автомобільно-технічному циклі, який очолював тоді полковник Оганов, ідеологічна робота там проводилась «про людське око», офіцери кафедри робили це неохоче, формально. Все ж головним завданням циклу було опанування численної автомобільної техніки, якої було достатньо, іiі ремонт та обслуговування, практичні водіння, інші речі, вкрай потрібні для вишколу кваліфікованих командирів автомобільної чоти (взводу) (Якимович, 2019, aydio 41:45).

Слід пам'ятати, що військова кафедра була не єдиною в Інституті структурною одиницею, метою якої була політико-пропагандистська діяльність. Заняття із політінформації проводились регулярно, офіцери кафедри викладали лекційний матеріал, однак досконалого 
знання із цього предмета не вимагали (Войтович, 2019, aydio 31:30), ця інформація мала радше інформаційний та рекомендаційний характер.

У другій половині 1980-х років на хвилі суспільних змін студенти багатьох цивільних вишів СРСР відкрито виступили проти військового навчання, передовсім через його обов'язковість. Крім того, причинами невдоволення студентів стали, по-перше, розрив між рівнем викладання у вишах профільних дисциплін за спеціальністю і рівнем військового навчання; по-друге, невідповідність, у багатьох випадках, профілю і змісту програм вишколу офіцерів запасу (Феськов, 2013:28).

Із наростанням антимілітарних поглядів у молоді, бойкотуванням студентами військових кафедр, поширення по всьому СРСР студентських акцій протесту проти загальної військової повинності, військові кафедри вищих навчальних закладів опинились в ситуації, в якій вже потрібно було пропагувати молоді не так політичні порядки в країні, як відстоювати свою потрібність та необхідність військового навчання. На військових кафедрах вишів робили спроби заспокоїти студентів та дійти з ними певного компромісу (Муравський, 2008:82 - 83). Навчальну програму із військової підготовки було переглянуто та скорочено: так, наприклад, у Ризькому політехнічному інституті період військового навчання скоротили з трьох років до одного, однак ці дії адміністрація інституту обгрунтовувала аж ніяк не $з$ політичного боку, а підкреслювала важливість виробничого навчання студентів над військовим (3 життя вузів краӥни, 1989:4). Викладачі військових кафедр спільно з адміністраціями вишів організовували бесіди із студентами (Шлаїн, 1983:3), писали статті у студентські газети, щоб заохотити молодь проходити військовий вишкіл та переконували у його необхідності.

Не став винятком і Львівський університет (тепер - Львівський національний університет імені Івана Франка). Так, студенти почали відкрито говорити або про реформу військової кафедри і зменшення кількості годин, відведених на військове навчання, або взагалі виступали проти вивчення військової справи (Миронюк, 1988:1). Резонансною у цьому питанні стала стаття студента факультету журналістики I. Ткаленка у стіннівці під назвою «Непереможна 
і легендарна», в якій він «ледь не ставив питання про доцільність Радянської Армії» та вимагав реформувати військове навчання (Миронюк, 1988:1).

Начальник військової кафедри Львівського університету К. І. Миронюк у відповідь на студентські вимоги погоджувався проводити реформи. У 1987-1988 н. р., враховуючи те, що багато студентів вже відслужили в армії до початку навчання на військовій кафедрі, відмінили заняття із загальновійськових статутів та муштрового вишколу, а сам начальник кафедри наголошував, що «це було зроблено з ініціативи кафедри»(Миронюк, 1988:1). Кафедра працювала також над удосконаленням форм і методів проведення занять, наприклад, у 1988 р. студенти факультету журналістики відвідали розгорнуту польову друкарню та редакцію газети (Миронюк, 1988:1).

Враховуючи пропозиції і побажання студентів, кафедра визначила терміни військового вишколу від п'ятого до восьмого семестрів, скоротивши програму на 100 год., відмінила обов'язкове самонавчання і тренування зі спеціальності, встановила для студентів довільну форму одягу та зачіски (Миронюк, 1988:1).

Наголосимо, що начальник кафедри франкового вишу був категоричним у питанні доцільності військового вишколу. «Заперечення військової підготовки у вишах - це пряме заперечення і закону СРСР про загальну військову повинність. Адже саме на його основі прийнято рішення про введення військової підготовки у вишах» (Миронюк, 1988:1).

Однак, попри активну полеміку щодо важливості військового вишколу, що вирувала в країні, i, зокрема, серед молоді Львова, автор не може стверджувати, що в Львівському політехнічному інституті ця проблема була настільки гострою. Лібералізація до студентства з боку військової кафедри Інституту однозначно була. Вже від 1988-1989 н. р. студентам дозволили різні стрижки, довільні одяг та взуття; скоротили кількість навчальних годин на військовій кафедрі (Слисеєв, 1989:4). Автор не знайшла інформацію стосовно бойкоту студентами Політехніки військового навчання. Навпаки, в Інститутській пресі зустрічаються статті самих студентів, які мали на меті переконати читачів у потрібності військового вишколу, зауважуючи, що на військовій кафедрі студенти не 
тільки отримували військову спеціальність, але й навички водіння, брали активну участь у військово-патріотичних заходах, політінформаціях, екскурсіях (Рожков, 1988:3).

Керівництво Інституту проводило кампанії, щоб заохотити молодь проходити військовий вишкіл. Так і надалі до радянських свят офіцерів військової кафедри нагороджували грамотами, а про їхню військову звитягу розповідали на урочистостях та в студентській пресі (Йолтуховська, 1988:1-3).

Отже, військова кафедра мала на меті не лише вишкіл студентів, але й була політико-ідеологічною одиницею Львівського політехнічного інституту.

1. Офіцери військової кафедри проводили активну військовополітичну роботу в Інституті. При кожному факультеті призначали факультетського курсового офіцера, завданням якого було проводити військово-політичні та патріотичні заходи; він вивчав біографії студентів, що навчались на кафедрі, заводив на кожного студента окрему особову справу, писав на них характеристики.

2. Окрім цього, усі викладачі військової кафедри брали активну участь у проведенні в Інституті політичних заходів, організовували військово-патріотичні бесіди, екскурсії та вечори.

3. Важливим внеском офіцерів кафедри в ідеологічну діяльність Інституту були їхні статті у студентській газеті, які пропагували комуністичні догми, вихваляли здобутки Радянської Армії у Другій світовій війні, досягнення у радянській військовій справі.

4. Військово-патріотична робота зі студентами призвела, 3 одного боку, до розуміння та прийняття студентами свого військового обов'язку, а з іншого, надмірна політична заангажованість суспільства у всіх сферах діяльності вплинула на назрівання в кінці 1980-х років антимілітарних поглядів у молоді. Однак, у порівнянні, наприклад, із Львівським університетом імені Івана Франка, у Львівській Політехніці перехід від військового навчання Радянської Армії до Української був плавним - це було спричинено передовсім тим, що в Політехніці було значно більше військово-технічного вишколу і він явно переважав над ідеологічною пропагандою.

У подальших студіях актуально дослідити та зробити порівняння політико-пропагандистської діяльності військових кафедр вищих навчальних закладів Львова. 


\section{Використані посилання}

Голиков В. И., ред. 2013. Вооруженные Силы СССР после Второй мировой войны: от Красной Армии к Советской. Ч. 1: Сухопутные войска, Томск: Издательство научно-технической литературы, с. 28.

Голубєв А. П. 1947. Партія Леніна-Сталіна - натхненник i організатор перемог. Радянський студент, 23 лютий 1947, № 6, с. 2.

Державний архів Львівської області (далі - ДАЛО) Ф. Р-120: Львівський політехнічний інститут, Історична довідка ЛПІ., арк. 6. Посилаючись на Ф. Р-120, оп. 32, спр. 2, арк. 11-13, 29-30.

ДАЛО. Ф. П-380: Партійний комітет ЛПІ, оп. 1. спр. 68: Протоколи засідань партійного бюро за 1950 р., арк. 283.

ДАЛО. Ф. П-380: Партійний комітет ЛПІ, оп. 1, спр. 353: Протоколь партийных собраний военной кафедры ЛПИ (17.03.1960-29.12.1960)., арк. 78.

ДАЛО. Ф. Р-120: Львівський політехнічний інститут, оп. 12, спр. 109: Протоколь заседаний кафедры за 1951-1952 учебный год., арк. 35.

ДАЛО. Ф. Р-120: Львівський політехнічний інститут, оп. 12, спр. 123: Протоколь заседаний кафедры за 1952-1953 учебный год., арк. 34.

Слисеєв А. 1989. Невже не можна знайти вирішення? Радянський студент, 8 лютого 1989, № 4, с. 4.

3 життя вузів країни. 1989. Радянський студент, 25 січня 1989, № 3, c. 4.

Зінченко М. 1976. Добра традиція. Радянський студент. 4 лютого 1976, с. 2.

Йолтуховська Л. 1988. Це просто щастя - знати їх. Радянський студент, 23 лютого 1988, № 9, с. 1-3.

Кулик С. 1947. Штурм міста Черкаси. Радянський студент. 23 лютого 1947, № 6, с. 3.

Ляшенко I. 1947. Артилерія Радянської Армії. Радянський студент, 20 листопада 1947, с. 2.

Мадеєв Г. 1949. Конструктор російської гвинтівки. Радянський студент, 5 травня 1949, № 17. с. 4.

Миронюк К. І. 1988. Пам'ятати про обов'язок. За радянську науку, 22 листопада 1988, № 32, с. 1. 
Муравський О. 2008. Студентство України за демократичне вирішення питання військової підготовки наприкінці 80-х початку 90-х років XX ст. Військово-науковий вісник Національної академії сухопутних військ імені гетьмана Петра Сагай-дачного, Випуск 10, с. 81-89.

Навчання на військовій кафедрі Львівського політехнічного інституту: інтерв'ю із д.і.н., професором, завідувачем кафедри середніх віків та візантиністики ЛНУ ім. Івана Франка Леонтієм Войтовичем, підготувала Лариса Шелестак. 2019. ЛНУ ім. Івана Франка. 15 січня 2019, с. 10.

Навчання на військовій кафедрі Львівського політехнічного інституту: інтерв'ю із д.і.н., професором кафедри історичного краєзнавства ЛНУ ім. Івана Франка Богданом Якимовичем, підготувала Лариса Шелестак. 2019. ЛНУ ім. Івана Франка. 12 лютого 2019, c. 12.

Постановление Совета Народных Комиссаров СССР № 413 от 13 апреля 1944 г. "О военной подготовке студентов высших учебных заведений», [online] Доступно: < http://bdsa.ru/D0\%B4/ 820-668> [Дата звернення 1 лютого 2019].

Рожков В. 1988. Наша друга професія. Радянський студент, 23 лютого 1988, № 9, с. 3.

Сморчков С. 1975. Розповідь про нескорених. Радянський студент, 4 березня 1975, № 8, с. 2.

Чернілевський К. 1947. Форсування річки Серет. Радянський студент, 23 лютого 1947, № 6, с. 3.

Шлаїн Я.Н. 1983. Зустріч з ректором. За радянську науку, 15 лютого 1983, № 5, с. 3 .

\section{REFERENCES}

Golikov V. I., ed. 2013. Armed Forces of the USSR after the Second World War: from the Red Army to the Soviet. Part 1: Land Forces, Tomsk: Publishing House of Scientific and Technical Literature, p. 28 (rus).

Golubev A. P. 1947. The Party of Lenin-Stalin - the inspire and organize victories", Soviet student, 23 February 1947, No. 6, p. 2 (rus).

State Archives of Lviv Region (hereinafter - SALR) F. R-120: Lviv Polytechnic Institute, Historical Reference of LPI, sheet 6. Referring to: fond R-120, series 32, file 2, sheet 11-13, 29-30 (ukr). 
SALR. F.P-380: Party Committee of LPI, series 1, file 68: Protocols of the assembly of the party organization for 1950, sheet 283 (rus).

SALR. F.P-380: Party Committee of LPI, series 1, file 353, Protocols of the assembly of the military department of LPI (03/17/1960-29.12.1960), sheet 78(rus).

SALR. fond R-120: Lviv Politechnic institute, series 12, file 109, Protocols of the assembly of the department for 1951-1952, sheet 35 (rus).

SALR. fond R-120 Lviv Politechnic institute: series 12, file 123, Protocols of the assembly of the department for 1952-1953, sheet 34 (rus).

Yeliseyev, A. 1989, Is it possible to find a solution? Soviet student, No. 4. p. 4(ukr).

From the life of universities of the country. 1989, Soviet student, 25 January 1989, No. 3, p. 4 (ukr).

Zinchenko M. 1976. Good Tradition. Soviet student, 4 February 1976, p. 2 (ukr).

Yoltukhovska L. 1988. This is just a happiness to know them, Soviet student, 23 February 1988, No. 9, p. 1-3 (ukr).

Kulik S. 1947. Assault of the city Cherkasy, Soviet student, 23 February 1947, No. 4, p. 3 (ukr).

Lyashenko I. 1947. Artillery of the Soviet Army, Soviet student, 20 November 1947, p. 2 (ukr).

Madeev G. 1949. Inventor of the Russian rifle, Soviet student, 5 May 1949, No.17, p. 4 (ukr).

Myronyuk K. I. 1988. To Remember the duty, For Soviet Science, 22 November 1988, No. 32, p. 1 (ukr).

Muravskyi O. 2008. Student of Ukraine for a democratic solution to the issue of military training in the late 80's and early 90's of the XX century", Military Scientific Herald of the Hetman Petro Sahaidachnyi National Army Academy, Issue 10, pp. 81-89 (ukr).

Studying at the military department of the Lviv Polytechnic Institute: an interview with D.Sc., Professor, Head of the Department of Middle Ages and Byzantine Studies Leontiy Voitovich, LNU Ivan Franko, prepared by Larysa Shelestak. 2019. LNU Ivan Franko. 15 January 2019, p.10 (ukr).

Studying at the military department of the Lviv Polytechnic Institute: an interview with D.Sc., Professor of the Department of historical regional studies Bogdan Yakimovich, LNU Ivan Franko, 
prepared by Larysa Shelestak. 2019. LNU Ivan Franko. 12 February 2019, p.12 (ukr).

Resolution of the Council of People's Commissars of the USSR No. 413 of April 13, 1944 «On military training of students of higher educational institutions» [online] Available at:

<http://bdsa.ru/D0\%B4/820-668> [Accessed 1 February 2019] (rus).

Rozhkov V. 1988. The our second profession. Soviet student, 23 February 1988, No. 9, p. 3 (ukr).

Smorchkov S. 1975. The Story about unbroken. Soviet student, 4 March 1975, No. 8, p. 2 (ukr).

Chernilevskiy K. 1947. Forcing the River Seret. Soviet Student, 23 February 1947, No. 6, p. 3 (ukr).

Shlain Ya. N. 1983. Meeting with the Rector. For Soviet Science, 15 February 1983, No. 5, p. 3 (ukr).

\section{Shelestak L.}

MILITARY DEPARTMENT OF THE LVIV POLYTECHNIC INSTITUTE AT THE SERVICE OF THE SOVIET IDEOLOGY (1944-1991)

The Soviet military training system unfolded at the universities of Lviv during the last period of the German-Soviet war, by the order of the People's Commissar of Defense of the USSR No. 75 and by the Resolution of the People's Commissariat of the USSR No. 413 from April 13, 1944, which restored military and naval training in higher civilian educational institutions of the USSR. According to these legal documents, the aim of military training was "educating the students youth in the love to the Motherland and the devotion to the Soviet authorities". The military department of the Lviv Polytechnic Institute was founded after the restoration of the Institute in the early 19441945.

The main idea of the research to investigate the role of the military department in the political education of students of one of the largest universities of Lviv in the Soviet period, to comprehensively consider the ideological and political functions of the officers of the department. Author were trying to investigate methods of political influence on student's youth, to show main ways to inform and spread communist dogmas, popularize military service and achievements of the Soviet Army. 
In this research author used the materials of the State Archive of the Lviv region: the fund of the Lviv Polytechnic Institute of the Soviet period, R-120 and the fund of the Party Committee of the Lviv Polytechnic Institute - P-380. The materials of the «Soviet student institute's newspaper» were used for the analysis of the political and ideological activities of officers of the military department. To confirm author's arguments, were used interviews with graduates of Lviv Polytechnic Institute, which give us some characteristic of the political work of the department.

The tasks of military department of Lviv Polytechnic Institute were not only just training the officers. It also served as a key link in the ideological and political work. In order to identify «Ukrainian bourgeois nationalists», the teachers of the department filled up so called personnel file for every student, with information about origin, parents and family.

As a conclusion we need to say that the military department of the Lviv Polytechnic Institute conducted active political and propaganda work with students, who were often involved in various kinds of political events and celebrations. Military patriotic work with students led, on the one hand, to the understanding and acceptance by students their military duty, and on the other hand, the excessive political engagement influenced the maturing of anti-militaristic attitudes among young people in the late 1980s.

Keywords: military department, Lviv polytechnic institute, ideology, reserve officers. 